\title{
Strategically-Oriented Enterprise Management through Information Systems
}

\author{
Oksana Zybareva, Liudmyla Verbivska, Inna Lopashchuk, Olga Kalaman, Tatyana Derkach \\ Nataliia Smentyna
}

\begin{abstract}
Complex administrative processes in the conditions of increasing instability in the external environment and destructive methods of globalization determine the relevance of the strategically oriented enterprise management, which includes the formation of an optimal development strategy that takes into account economic and social, technological and other essential factors.The use of information systems in the strategic management of the enterprise requires a more detailed study. The use of information systems in strategic management allows us to formulate ideas about specific "bottlenecks" in the activities of the senterprise based on the information gathered and respond adequately and promptly to them. The prospect of further research may be the study of the use of other information systems in strategic management.
\end{abstract}

Index Terms: Information Systems,Management,Project Expert.

\section{INTRODUCTION}

Complex administrative processes in the conditions of increasing instability in the external environment and destructive methods of globalization determine the relevance of the strategically oriented enterprise management, which includes the formation of an optimal developsment strategy that takes into account economic and social, technological and other essential factors. The use of information systems in strategic management will increase the efficiency of the company's activity and competitiveness, optimize the costs associated with the functional management system.

The research of various aspects of strategic management (the definition of its essence, conceptual foundations,

Revised Manuscript Received on 30 July 2019.

* Correspondence Author

Oksana Zybareva*, Department of Business, Trade and Stock Exchange Operations, Yurii Fedkovych Chernivtsi National University, Chernivtsi, Ukraine

Liudmyla Verbivska, Department of Business, Trade and Stock Exchange Operations, Yurii Fedkovych Chernivtsi National University, Chernivtsi, Ukraine

Inna Lopashchuk, Department of Business, Trade and Stock Exchange Operations, Yurii Fedkovych Chernivtsi National University, Chernivtsi, Ukraine

Olga Kalaman, Department of Management and Logistics, Odessa National Academy of Food Technologies, Odessa, Ukraine

Tatyana Derkach, Department of Management, International Humanitarian University, Odessa, Ukraine

Nataliia Smentyna, Department of Economics, Law and Business Management, Odessa National EconomicUniversity, Odessa, Ukraine.

(C) The Authors. Published by Blue Eyes Intelligence Engineering and Sciences Publication (BEIESP). This is an open access article under the CC-BY-NC-ND license http://creativecommons.org/licenses/by-nc-nd/4.0/ methodological and organizational principles, recommendations) deals with the works of such scholars: S.A. Chevereva, E.S. Popova, O.I. Grevtsev and T.B. Efimova [1], O. M. Ovdiuk [2], I.V. Shindryaeva [3], I. Bashynska [4-5], O. Prokopenko [6], C.E. Stoenoiu [7], S Bondarenko, I. Liganenko, O. Kalaman and L. Niekrasova [8], O. Kalaman [9], O. Goncharenko[10], O. Salnikova [11], Dźwigoł [12] and others.

However, it requires a more detailed study of the application of information systems in the strategic management of the enterprise.

\section{Formulating the goals of the article}

Consequently, the main task of the article is to show the application of information systems as a tool of strategic management, to provide their algorithms of action and practical examples of use.

\section{METHODOLOGY}

Increasing the quality and efficiency of information collection and processing, forecasting; efficiency and rationality of decision-making will promote the use of information systems in the strategic-oriented management of the enterprise.

A strategic information system is called a computer system that allows you to realize strategic goals that are promising for enterprise development and provide support for decision-making.

The place of the information system in strategic management is shown in Fig. 1.

The first component of strategic management is strategic planning, which includes analysis of the internal and external environment; at this stage, a choice is made from several alternatives. The second component is the implementation of a strategy that includes its organization and execution. The third component is strategic control, which includes monitoring and monitoring of results from strategic activities; tracking the implementation of the strategy; correction of plans (goals) if necessary. 


\section{Strategically-Oriented Enterprise Management through Information Systems}

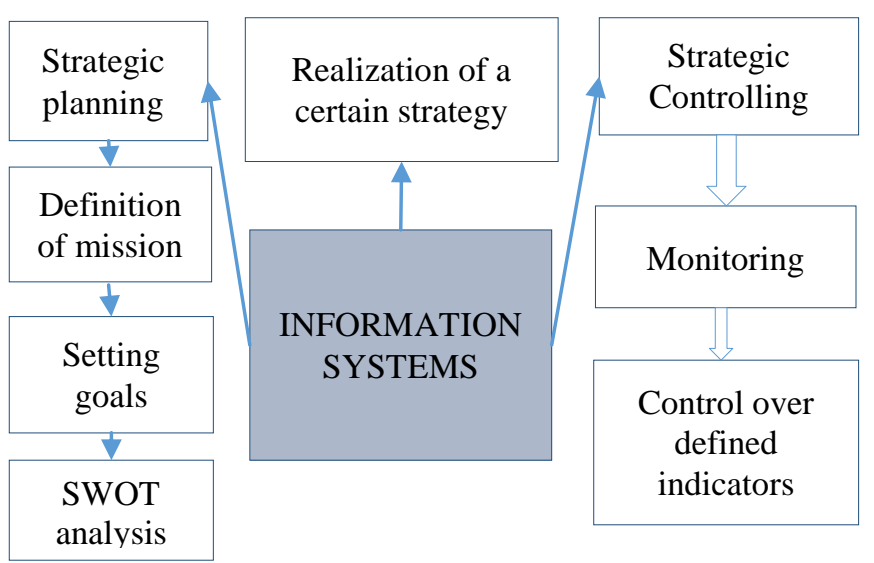

Fig. 1The role of the information system in enterprise management in Fig. 2.

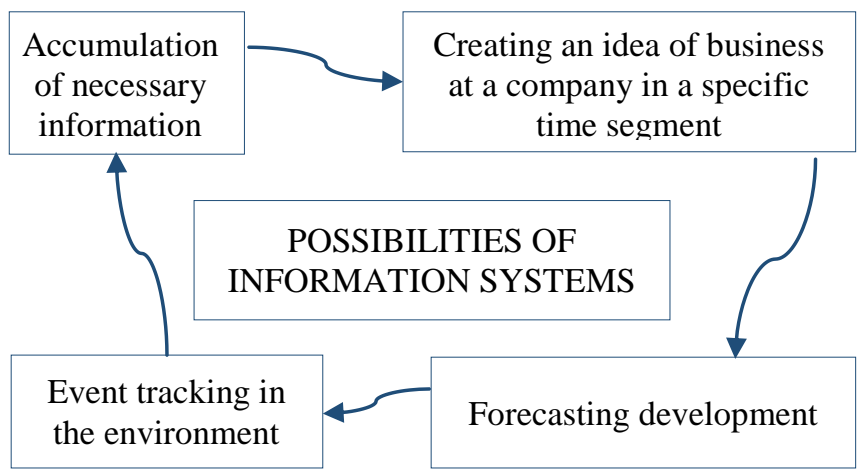

Fig. 1 Possibilities of strategic systems in enterprise management

The purpose of a strategic information system is to provide information that is necessary for decision-makers, to compare changes in the external (legislative, political, currency, economic, marketing and other influences) and internal environment (operational level) with the capabilities of the enterprise. systems: choice among possible sources of financing, attraction of potential and future investors, search of new marketing markets, launch of new products and their promotion, reengineering and engineering of business processes, solution of unstructured tasks, planning on long-term perspective, evaluation of the prospects of certain projects, investments or investments.

Decision support systems help determine the main lines of business in the long run. Characteristic features of the tasks of these systems are the prevalence of qualitative assessments over quantitative, the complexity of formalizing restrictions and goals, flexibility and adaptation to change. Due to the inconsistency and incompleteness of information available to persons responsible for making strategic decisions, various methods are used such as expert, statistical analysis, modelling (in particular simulation and mathematical), fuzzy logic, neural networks. Such information systems are based on the technology of detecting the laws of hidden or data mining (Data Mining). The disadvantages of decision support systems are their high cost, which is due to the use of sophisticated programming methods; some systems have
Opportunities of strategic information systems are shown

Strategic level tasks solved with the help of information

limited analytical capabilities.

Strategic decision support systems allow you to create reports, manage data warehouse and metadata, visualize, process and upload data, perform analytical queries (OLAPs), analyze time series, forecast and simulate, use mathematical and statistical algorithms. There is also an opportunity to do an analysis of "what will happen if ..." and "what you need to ..." in order to make the right decision, to clearly show the results of analysis in the form of charts, maps, diagrams; detailing the indicators regardless of the type of activity in order to see the real situation in the enterprise.

The optimal result of the use of strategic information systems is possible with the synergy of the two approaches: the first is the adaptation of the information system to the strategy only after formulating the goals and strategy, and the second - the use of the system during strategic planning and formulation of goals.

Let's look at one of the information systems (Project Expert), which allows you to make strategic decisions in more detail. The system's operation is based on simulation, which shows the performance of the research enterprise and predicts flows (monetary or material) for a specified period. The purpose of the system is to develop financial plans and investment projects and to determine their effectiveness and suitability. Modelling is carried out regardless of scale, industry, the complexity of the project. It is also possible to estimate the margin of safety and the maximum level of risk, to distinguish the effectiveness of each participant's investments; look at various options for buying, selling; control the implementation of the project.

The Project Expert's algorithm is shown in Fig. 3.

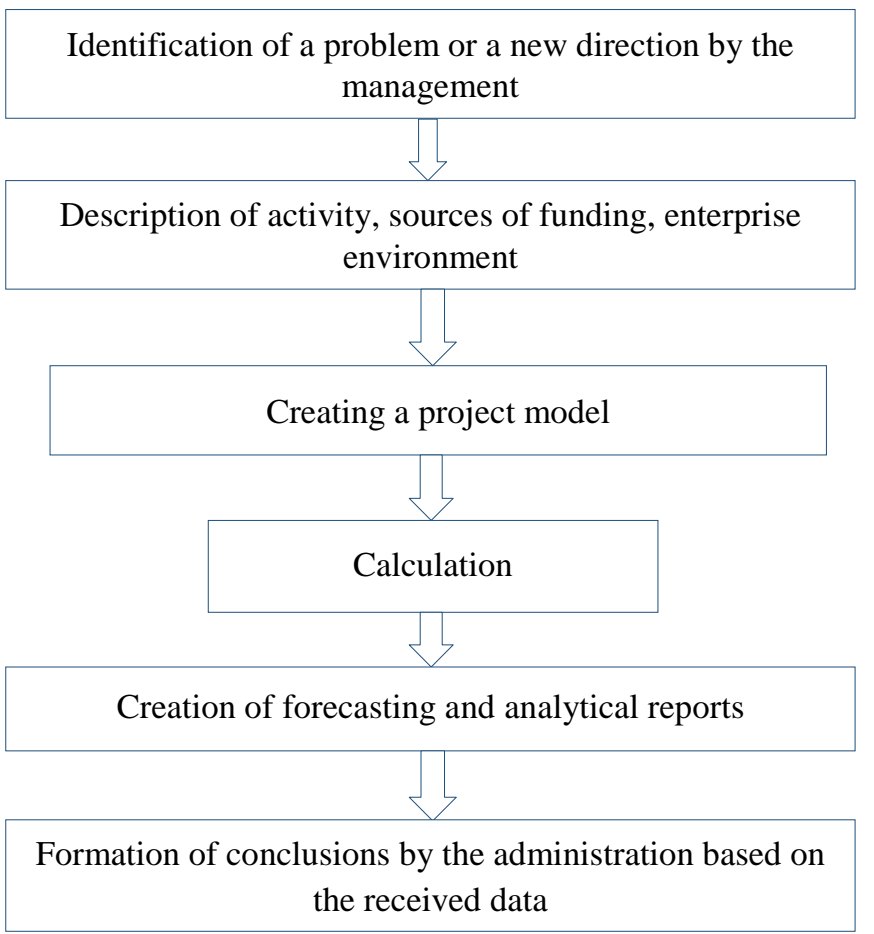

Fig. 3 Project Expert Project Steps

Published By: 
Output data (example data are conditional). Let the LLC "SDR", which is engaged in the production and sale of bakery products, has decided to release a new product: frankenlaib, and determine the feasibility of this implementation. The project start date is 01/08/2019. Duration - 1 year. Date of commencement of sales - 04/08/2019. The balance sheet of the enterprise: assets: cash $-\$ 100000$; building - shop - \$ 200000; equipment - machine $-\$ 50000$, the percentage of wear $-30 \%$, depreciation period -120 months. The principle of inventory accounting is FIFO.

Calendar plan: preparation of equipment (01.08-02.08), formation of stock of raw materials (02.08-03.08), production (3.08).

Taxes, fees, contributions: income tax - 18\%; VAT - 20\%; PIT - 18\%; military fee - 1,5\%; ECU - 22\%. Tax base: profit (income tax); salary (personal income tax, military salary, ECU), value added (VAT). The formation of reserves is $20 \%$ profit.

Sales plan: price - \$ 10; sales volume (units): 8.2019 $3000 ; 9.2019$ - 5000; 10.2019 - 5300; 11.2019 - 6000; 12.2019 - 6600; 1.2020 - 7000; 2.2020 - 7500; 3.2020-7.2020 - 8000 .

Personnel: salary: director - \$ 6000; accountant - \$5000; driver - \$3500; cleaner - \$ 3000 .

Production plan: Specific costs: flour - 0,025 kg; milk 0,01 l.; filler - 0,01 \$, electricity - 0,02 kWh. Working wage baking - 0,3 \$/unit; sale - 0.2 \$/unit. Other expenses: transport -- 0,2 $\$$. Schedule of production - the volume of production is unlimited.

Raw materials and supplies: price: flour $-8 \$ / \mathrm{kg}$, milk: 10 \$/l; filler - 8 \$/unit; electricity - 2 \$/kWh.

After the final filling of the data, the program will have the opportunity to view the reports: profit-loss, cash flow, financial indicators, sensitivity analysis, use of profits and many more.

Here is an algorithm of action in Project Expert according to the data of the investigated enterprise in Fig. 4.

The decision to release a new type of product (Frankenlaib)

Description of activity of LLC "SDR ", sources of financing, the environment of the enterprise

Creating a project model

Calculation of indicators

Creation of forecast and analytical reports: profit-loss, cash flow, break-even point, investment efficiency

Formation of conclusions by the management on the profitability and feasibility of the project

\section{Fig. 4 Creating a model of LLC "SDR" in Project Expert}

The profit-loss report is shown in Fig. 5. It can be seen from the figure that the project is profitable in all quarters except for the 8th and 9th months of 2019. The management should optimize the sale of products, price margins or production costs.

\begin{tabular}{|l|c|c|c|c|c|}
\hline & $8-92019$ & 4 qua. 2019 & 1 qua. 2020 & 2 qua. 2020 & 7.2020 \\
\hline$\rightarrow$ Gross sales & 66666,67 & 149166,67 & 187500,00 & 200000,00 & 66666,67 \\
\hline Losses & & & & & \\
\hline Sales taxes & & & & & \\
\hline Net sales & 66666,67 & 149166,67 & 187500,00 & 200000,00 & 66666,67 \\
\hline $\begin{array}{l}\text { Materials and } \\
\text { components }\end{array}$ & 3873,33 & 9248,33 & 11625,00 & 12400,00 & 4133,33 \\
\hline Part-time salary & 5660,00 & 12664,25 & 15918,75 & 16980,00 & 5660,00 \\
\hline Total direct costs & 9533,33 & 21912,58 & 27543,75 & 29380,00 & 9793,33 \\
\hline Grogs profit & 57133,33 & 127254,08 & 159956,25 & 170620,00 & 56873,33 \\
\hline Property tax & & & & & \\
\hline Administrative expenses & & & & & \\
\hline Production costs & & & & & \\
\hline Marketing costs & & & & & \\
\hline $\begin{array}{l}\text { Salary of administrative } \\
\text { staff }\end{array}$ & 49525,00 & 74287,50 & 74287,50 & 74287,50 & 24762,50 \\
\hline $\begin{array}{l}\text { Wages of production } \\
\text { personnel }\end{array}$ & & & & & \\
\hline $\begin{array}{l}\text { Wages of marketing } \\
\text { personnel }\end{array}$ & & & & & \\
\hline $\begin{array}{l}\text { Total permanent } \\
\text { expenges }\end{array}$ & 49525,00 & 74287,50 & 74287,50 & 74287,50 & 24762,50 \\
\hline Amortization & 1500,00 & 2250,00 & 2250,00 & 2250,00 & 750,00 \\
\hline Interest on loans & & & & & \\
\hline $\begin{array}{l}\text { Total non-productive } \\
\text { costs }\end{array}$ & 1500,00 & 2250,00 & 2250,00 & 2250,00 & 750,00 \\
\hline Other income & & & & & \\
\hline Other expenses & 13765,00 & & & & \\
\hline $\begin{array}{l}\text { Losses of previous } \\
\text { periods }\end{array}$ & & 7656,67 & & & \\
\hline Profit before tax & $-7656,67$ & 50716,58 & 83418,75 & 94082,50 & 31360,83 \\
\hline $\begin{array}{l}\text { Total expenses attributed } \\
\text { to profit }\end{array}$ & & & & & \\
\hline $\begin{array}{l}\text { Profit from exchange rate } \\
\text { difference }\end{array}$ & & 7750,92 & 83418,75 & 94082,50 & 31360,83 \\
\hline Taxable profit & & 15015,38 & 16934,85 & 5644,95 \\
\hline Income tax & & & & & 25715,88 \\
\hline Net profit & & & & & \\
\hline
\end{tabular}

Fig. 5 Profit and loss account, \$

The cash flow statement is shown in Fig. 6. The report shows cash inflows and disbursements for significant items

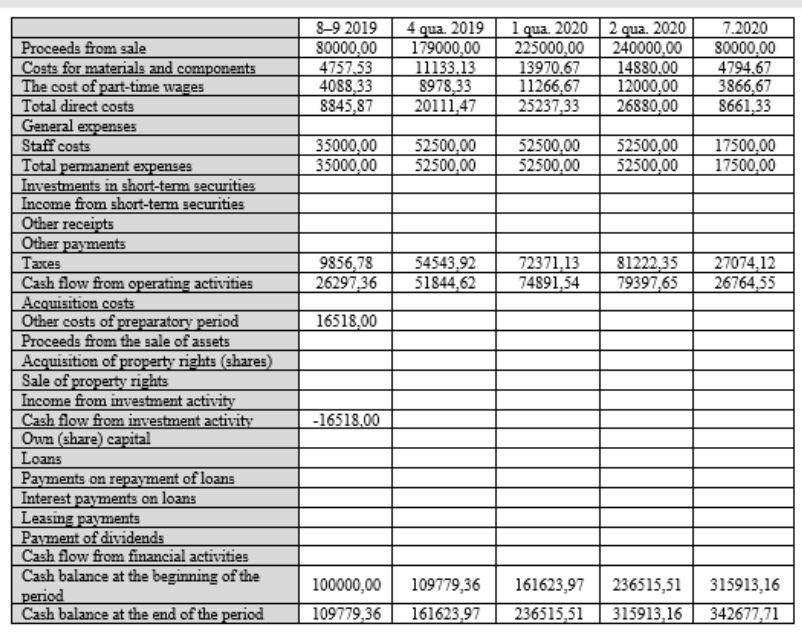

Fig. 6 Cash flow statement, \$

Published By: 


\title{
Strategically-Oriented Enterprise Management through Information Systems
}

Calculation of the break-even point in a quantitative measurement is shown in Fig. 7. The forecast shows the average number of products that need to be realized per month in order not to get a loss. One can see that the damage in August is due to the implementation of less than the break-even, namely 3000 units. In all other months, the volume of sales is more than a break-even point.

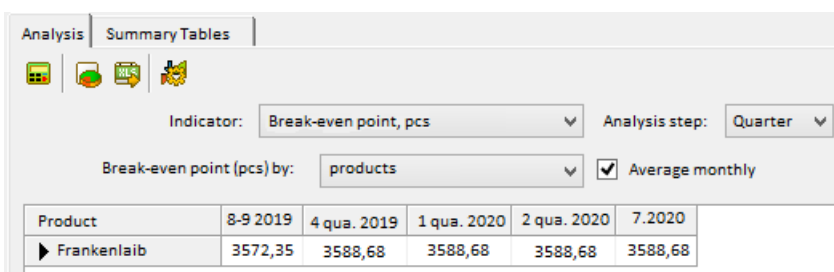

Fig. 7 Break-even point, units

The calculation of investment efficiency is shown in Fig. 8. The report reflects the indicators of the investment project analysis. The payback period of the project is 2 months on the condition that the discount rate is $0 \%$. NPV is 242677.71 UAH.

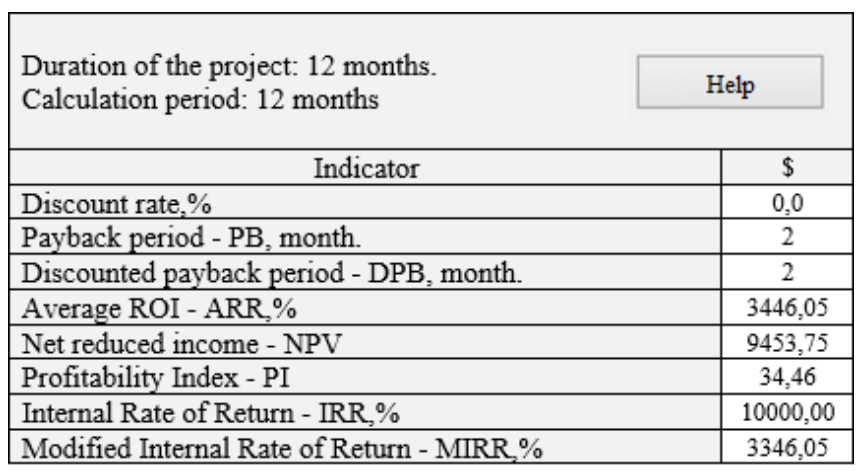

Fig. 8 Determine The Effectiveness Of The Investment

\section{Analysis of the results}

The project is profitable as a whole, and it is expedient to implement it by LLC "SDR".

\section{CONCLUSION}

Taking into account changes in the environment through information systems management is determined by the directions of the enterprise, formulate the purpose and strategy, identify the resources needed for this and get the most effect from the use.

The use of information systems in strategic management allows us to formulate ideas about particular "bottlenecks" in the activities of the enterprise based on the information gathered and respond adequately and promptly to them. The prospect of further research may be the study of the use of other information systems in strategic management.

\section{REFERENCES}

1. S.A. Chevereva, E.S. Popova, O.I. Grevtsev and T.B. Efimova. Digital Technologies in Enterprise Management, Problems of Enterprise Development: Theory and Practice 2018, SHS Web of Conferences 62, 11003, 2019,

2. Ovdiuk O. M. (2019), "Managerial decisions in the technology of enterprises' management", Efektyvna ekonomika, [Online], vol. 6, available at http://www.economy.nayka.com.ua/?op=1\&z=7120. DOI: 10.32702/2307-2105-2019.6.48.

3. I.V. Shindryaeva et al. 2019 IOP Conf. Ser.: Mater. Sci. Eng. 483 https://doi.org/10.1088/1757-899X/483/1/012059
4. I. Bashynska et al. Smart Solutions: Risk Management of Crypto-Assets and Blockchain Technology, International Journal of Civil Engineering and Technology (IJCIET) 10(2), 2019, pp 1121-1131

5. I. Bashynska et al. Risk management methodology based on a risk management culture, unpublished

6. O. Prokopenko et al. Analysis of ICT Application in Technology Transfer Management within Industry 4.0 Conditions (Education Based Approach) // ICT in Education, Research and Industria Applications. Integration, Harmonization and Knowledge Transfer (ICTERI 2018): Proceedings of the 14th International Conference on ICT in Education, Research and Industrial Applications. Integration, Harmonization and Knowledge Transfer. Volume I: Main Conference (Kyiv, Ukraine, May 14-17, 2018) / Edited by V. Ermolayev, M.C. Suárez-Figueroa, A. Ławrynowicz, R. Palma, V. Yakovyna, H.C. Mayr, M. Nikitchenko, A. Spivakovsky. - Kyiv, ISSN 1613-0073, 2018. - Vol-2105. - P. 258-273

7. C.E. Stoenoiu. Patterns in enterprise management software, https://doi.org/10.1515/cplbu-2017-0038, 2018

8. S. Bondarenko, I. Liganenko, O. Kalaman and L. Niekrasova, Comparison of Methods For Determining The Competitiveness of Enterprises To Determine Market Strategy, International Journal of Civil Engineering and Technology (IJCIET) 9(13), 2018, pp. 890-898

9. S. Bondarenko, V. Lagodienko, I. Sedikova and O. Kalaman, Application of Project Analysis Software in Project Management in the Pre-Investment Phase, Journal of Mechanical Engineering and Technology, 9(13), 2018, pp. 676-684

10. O. Goncharenko et al. Improving Staff Stimulation Systems: Causal-Consequence Approach, International Journal of Engineering and Advanced Technology (IJEAT), Volume-8 Issue-5, June 2019, pp. 891-894

11. O. Salnikova. Matrix approach to risk management in the national security system, highlighting the criteria for choosing the optimal strategy for decision making, International Journal of Engineering and Advanced Technology (IJEAT), Volume-8 Issue-5, June 2019, pp 2407-2411

12. H. Dźwigoł, D. Dźwigoł. Time management in the process of enterprise https://doi.org/10.29119/1641-3466.2018.118.10, 2018 management

(n)

.

(1)

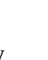

